\title{
60 YEARS AFTER PETER KAWERAU
}

\section{REMARKS ON THE SOCIAL AND CULTURAL HISTORY OF SYRIAC-ORTHODOX CHRISTIANS FROM THE XI ${ }^{\mathrm{TH}}$ TO THE XIII ${ }^{\mathrm{TH}}$ CENTURY}

In the year 1960 the second edition of the monograph by Peter Kawerau (1915-1988) with the title "Die jakobitische Kirche im Zeitalter der syrischen Renaissance: Idee und Wirklichkeit" was published ${ }^{1}$. Accepted as a doctoral dissertation in 1948, Kawerau presented a well structured analysis of the history of the Syriac-Orthodox Church from the $\mathrm{XI}^{\text {th }}$ to the $\mathrm{XIII}^{\text {th }}$ century. He wrote in a simple and precise language, his range of sources was admirably wide, and he did not need more than 108 densely documented pages of text. Appendices and a comprehensive bibliography, which are still useful today, were added. Although the work was never translated into English, the book influenced generations of theologians and philologists working on the SyriacOrthodox Church. It is also widely read and appreciated by SyriacOrthodox intellectuals, clerics as well as laymen'. The term "Syriac renaissance" was already well established as a key to this period. Philological research of the $\mathrm{XIX}^{\text {th }}$ and $\mathrm{xx}^{\text {th }}$ century considered the period between the $\mathrm{XI}^{\text {th }}$ and the $\mathrm{XIII}^{\text {th }}$ century as the last bloom in the seemingly inexorable decline of the Syriac-Orthodox Church from the viII ${ }^{\text {th }}$ century onwards until the Modern Era ${ }^{3}$.

One of the many achievements of Kawerau's work was its systematic approach as well as its social and cultural interests. Alongside the hierarchy of the church Kawerau analysed the structure of the lay communities. He offered observations about mentalities and identities of the Syriac-Orthodox population. In the last part of his book

1 P. Kawerau, Die jakobitische Kirche im Zeitalter der syrischen Renaissance. Idee und Wirklichkeit (Berliner byzantinistische Arbeiten, 3), Berlin, 1960 (= KaWERAU, Die jakobitische Kirche).

2 On Kawerau see K. PIngGéra, „Ex Oriente Lux“. Vom Sinn ostkirchengeschichtlicher Forschung an einer Evangelisch-Theologischen Fakultät - Gedanken zum 40jährigen Bestehen des Seminars für Ostkirchengeschichte in Marburg, in J. HAUPT (ed.), Ex Oriente Lux - Licht aus dem Osten. Theologische Wissenschaft und ökumenische Freundschaft (Hofgeismarer Protokolle 328), Hofgeismar, 2003, p. 17-37; C. WEISE, art. Peter Kawerau, in Bio-Bibliographisches Kirchenlexikon, XVII (2000), p. 776-781.

3 A. BAumstaRK, Geschichte der syrischen Literatur mit Ausschluß der christlichpalästinensischen Texte, Bonn, 1922, p. 285 (= BAUMSTARK, Geschichte der syrischen Literatur). 
Kawerau sketched the Syriac-Orthodox Church within the context of the multi-confessional and multi-religious world of the Medieval Near East.

The design of Kawerau's analysis had been suggested to him by Berthold Spuler (1911-1990), one of the most influential Orientalists in post-war Germany. Spuler, among his wide ranging research, cherished a great interest for Oriental Christianity ${ }^{4}$. Through his doctoral students he initiated a number of important contributions to the history of these churches, which have become standard reference works to the present day. Two younger doctoral dissertations with a similar structure together with Kawerau's work form a trilogy presenting the history of the SyriacOrthodox Church from the $\mathrm{v}^{\text {th }}$ to the XIII ${ }^{\text {th }}$ century. The first of these is the well known monograph by Wolfgang Hage on the earlier period of the history of the church. The second, written by Ilse Nabe-vonSchönberg, concentrates on the time between 800 and $1100 \mathrm{CE}$, and thereby closes the gap between Hage's and Kawerau's respective works ${ }^{5}$. In this context one should also mention another doctoral dissertation initiated by Spuler, the important monograph about the view of Syriac-Orthodox and Armenian chronicles on the crusades by Anneliese Lüders from $1964^{6}$.

Kawerau's book therefore structured a new field of investigation, followed by other works directly or indirectly related to Spuler's methodological initiatives ${ }^{7}$. It shall be used here, first, to systematize some of my own observations, mainly from analysing historiography. While following Kawerau's structure in general (see App.), I shall confine myself to commenting on certain chapters, which especially drew my attention. To reread Kawerau's study at the same time provides a useful starting point to reflect upon the state of research and the perspectives for investigations in social and cultural history in the future.

\footnotetext{
${ }^{4}$ Information provided by Prof. Dr. W. Hage/ Marburg; see B. SPULER (ed.), Handbuch der Orientalistik. Abt. 1, Bd. 8, Abschn. 2., Leiden - Köln, 1961, bzw. B. SPULER, Die morgenländischen Kirchen, Leiden, 1964; on works by Spuler see the bibliography in H.R. RöMER, A. NOTH, Studien zur Geschichte und Kultur des Vorderen Orients: Festschrift für Bertold Spuler zum 70. Geburtstag, Leiden, 1981.

5 W. HAGE, Die syrisch-jakobitische Kirche in frühislamischer Zeit, Wiesbaden, 1966; I.E.A. NABE VON SCHÖNBERG, Die westsyrische Kirche im Mittelalter (800-1150), Diss. theol., Heidelberg, 1976.

6 A. LÜDERS, Die Kreuzzüge im Urteil syrischer und armenischer Quellen, Berlin, 1964.

7 J.Th. NAVAKatesh, Die syrisch-orthodoxe Kirche der südindischen Thomas-Christen. Geschichte, Kirchenverfassung, Lehre (Das östliche Christentum, 19), Würzburg, 1967.
} 


\section{The Organisation of the Syriac-Orthodox Church}

\section{Patriarchs and suffragans}

The first part of Kawerau's monograph described the hierarchy and the organisation of the Syriac-Orthodox Church ${ }^{8}$. Kawerau investigated each level, starting with the patriarch at the top, the maphrian, i.e. the Primas of the Eastern part of the church formally in the Persian Empire, the metropolitans and the bishops, the abbots, the monasteries with the monks and nuns, and finally the lay community. In this field intensive research has taken place since then; the thorough work on the canonical law of the Syriac-Orthodox Church by Walter Selb ought to be mentioned in this respect. Selb also dealt with the hierarchy and the institutions of the church from the $\mathrm{XI}^{\text {th }}$ to the XIII ${ }^{\text {th }}$ century on a broad basis9. Legal sources have also been published. This material still awaits sociohistorical approaches, which are impeded by a very complex sourcecritical situation ${ }^{10}$.

Although the hierarchy of the Syriac-Orthodox Church is not yet entirely reconstructed for the period, progress has been made here as well. Jean-Maurice Fiey especially with his work "Pour un Oriens Christianus Novus" undertook to substitute in part the monumental "Oriens Christianus" by Michel LeQuien available to Kawerau" ${ }^{1}$. Still Kawerau's list of the patriarchs provides a view on the history of the church, which should be taken into account as a specific contribution. The differences come to light by comparison:

\section{(Table see p. 314)}

The varying reference numbers for the patriarchs shall not be discussed here. More important are the different periods of tenure. While Fiey decided which patriarch during a schism was to be considered legitimate and provided their periods of tenure accordingly, Kawerau sim-

8 Kawerau, Die jakobitische Kirche, p. 13-54.

9 W. SelB, Orientalisches Kirchenrecht, I. Die Geschichte des Kirchenrechts der Nestorianer, II. Die Geschichte des Kirchenrechts der Westsyrer (von den Anfängen bis zur Mongolenzeit) (Österreichische Akademie der Wissenschaften, philosophischhistorische Klasse, 388, 543), Wien, 1981, 1989 (= SELB, Orientalisches Kirchenrecht).

${ }^{10}$ Concerning the Syriac-Orthodox Church see for example A. Vööвus (ed. and transl.) The Synodicon in the West-Syrian Tradition, I-II. (CSCO, 367, Script. Syr., 161; CSCO, 375, Script. Syr., 163; CSCO, 368, Script. Syr., 162, CSCO, 376, Script. Syr., 164), Louvain, 1974-1976; W. SELB - H. KAUFHOLD, Das syrisch-römische Rechtsbuch I-III. I. Einleitung, II. Texte und Übersetzungen, III. Kommentar (Veröffentlichung der Kommission für antike Rechtsgeschichte, 9), Wien, 2002. 


\begin{tabular}{|c|c|}
\hline $\begin{array}{l}\text { THE LIST OF THE PATRIARCHS OF } \\
\text { THE XII } \text { TI }^{\text {TH }} \text { AND XII }{ }^{\mathrm{HH}} \mathrm{C} \text {. } \\
\text { BY PETER KAWERAU }\end{array}$ & $\begin{array}{l}\text { THE LIST OF THE PATRIARCHS OF } \\
\text { THE XII }{ }^{\mathrm{TH}} \text { AND XII }{ }^{\mathrm{TH}} \mathrm{C} . \\
\text { BY JEAN MAURICE FIEY }\end{array}$ \\
\hline & 1091-1129 Athanase VI bar Khamoro \\
\hline & 1120-1137 Jean X Mawdyono \\
\hline $1139-1166$ Athanasius VIII. & 1138/-1166 Athanase VII bar Qutreh \\
\hline 1166-1199 Michael I. der Große & 1166-1199 Michel I (l’Aîné, le Syrien) \\
\hline 1199-1207 Athansius IX. & 1199-1207 Athanase VIII \\
\hline 1199-1215 Michael II. & 1207-1215 Michel II (le Mineur) \\
\hline 1208-1220 Johann XIV. & 1215-1220 Jean XI \\
\hline 1222-1252 Ignaz II. & 1222-1252 Ignace III David \\
\hline 1252-1261 Dionys VII. & [1252-1261 Denys (Angūr)] \\
\hline 1253-1263 Johann XV. & 1253/61-63 Jean XII bar Ma dani \\
\hline 1264-1282 Ignaz III. & 1264-1283 Ignace IV Yešu \\
\hline 1283-1292 Philoxenus & 1283-1292 Philoxène Nemrud \\
\hline
\end{tabular}

ply listed the dates of their various assumptions of office. Both methods have their advantages. Kawerau's list however shows the schisms of the $\mathrm{XII}^{\text {th }}$ and XIII ${ }^{\text {th }}$ century at a first glance. Thus it provides a clear view of the gradual drifting apart of different geographic regions of the church. Hence, the early development of the schismatic situation of the centuries following the year 1292 comes to light. The Syriac-Orthodox Church branched into three patriarchates, the patriarchates of Sis, of Mardin, and of Melitene. Only in the second half of the $\mathrm{XV}^{\text {th }}$ century were they reunited $^{12}$. Neither the church in the Latin West nor the oriental churches were smoothly running machines; schisms used to be frequent all over Christianity during the period in question. At the same time the management of the churches under rulers of different religions or denominations was especially difficult. Socio-historical questions concerning conflict management and the means of ruling should substitute former speculations on the mentality of the Oriental Christians.

The patriarch was responsible for the integration of the Syriac-Orthodox communities living in different regions. During this period every

$"$ J.-M. FiEY, Pour un Oriens Christianus Novus (Beiruter Texte und Studien, 49), Beirut, 1993.

12 G. GRAF, Geschichte der christlichen arabischen Literatur, IV. Die Schriftsteller von der Mitte des 15. bis zum Ende des 19. Jahrhunderts, Syrer, Armenier, Kopten. Missionsliteratur, Profanliteratur (Studi e testi, 147), Città del Vaticano, 1951, IV, p. 811; I. BCHEIRY, L'attività siro-ortodossa nel Monte Libano nella seconda metà del sècolo $X V$, in Parole de l'Orient, 28 (2003), p. 609-658. 
endeavour has been made to secure this integration, not least by the symbolic representation of the patriarchal authority ${ }^{13}$. Since Patriarch Ignatius III David the name Ignatius is the one usually taken on by the new patriarch. The name reminded not only of the holy patriarch Ignatius, but also of the claim of the Syriac-Orthodox to orthodoxy and to the Holy See of Antioch. The same patriarch also upgraded the residence of the patriarchs in Antioch. Since the beginning of the Latin rule in the city the patriarchs had sought for representation there with varying success. Rituals of enthronisation of the newly elected patriarch in St. Peter's cathedral, held by the Latins, became frequent, even habitual ${ }^{14}$.

Increased endeavours notwithstanding, the integration of the church failed more and more. As early as the XII ${ }^{\text {th }}$ century the patriarch had little control in some regions, like in inner Syria, the Djazīra, Palestine or Cilicia, and there were mighty bishops that simply could not be coerced into obedience ${ }^{15}$. It is not always known, who was even responsible for a certain diocese. This is also true for the diocese of Antioch itself ${ }^{16}$.

As is well known, the weapons in the hands of the highest representative were rather blunt. The patriarch ruled by spiritual authority alone. Sanctions against bishops were effective only with the majority of the bishops and the communities consenting. When however they provoked schisms or opted for open opposition, there was little the patriarch was able to do. The rather weak internal power structure of the church, however, was not the only institution answerable for the problems of the time. The patriarch could not check on everything that may have been necessary. His area of control was defined by the rapidly changing political landscape. Insecurity and war limited the mobility of the patriarch considerably. Several times the patriarchal residence was relocated ${ }^{17}$. These conditions contributed to centrifugal forces on the local level.

13 On the crucial role of symbolic communication in the production of power and authority G. Althoff, f.e. G. Althoff, Die Macht der Rituale. Symbolik und Herrschaft im Mittelalter, Danmstadt, 2003.

14 J.B. AbBeloos - T.J. Lamy (ed. and transl.), Gregorii Barhebrei Chronicon Ecclesiasticum, I-III, Louvain 1872 - Paris, 1874, 1877 (= BAR 'EBRÖYÖ, Chronicon eccl. occ./ori.), p. 671-75 (syr.), p. 672-76 (lat.).

15 Kawerau, Die jakobitische Kirche, p. 70-71; D. Weltecke, Die "Beschreibung der Zeiten" von Mor Michael dem Großen (1126-1199). Eine Studie zu ihrem historischen und historiographiegeschichtlichen Kontext (CSCO, 594; Subsidia, 110), Louvain, 2003, p. 62, 69-73, 102-107, 109-116.

16 For a discussion see, D. Weltecke, On the Syriac Orthodox in the Principality of Antioch, in K. CiggaAR - M. MetCalf (ed.), East and West in the Medieval Eastern Mediterranean I. Antioch from the Byzantine reconquest until the end of the Crusader principality. Acta of the congress held at Hernen in May 2003 (Orientalia Lovaniensia Analecta, 147), Leuven, 2006, p. 95-124, esp. p. 100-107.

17 J.B. Снавот (ed. and transl.), Chronique de Michel le Syrien. Patriarche Jacobite 
For the actual management of the communities the most important figure was the metropolitan or the bishop respectively. The great Syriac-Orthodox chronicles by Michael the Syrian and by Bar 'Ebrōyō, however, mainly reflect the experiences and disappointments of the patriarchs and the maphrians. They pay little attention to the duties and worries of suffragans as a matter of interest in its own right. Also they tend to interpret conflicts between bishop and patriarch personally and morally, not structurally. This bias of the tradition requires source critical regard.

\section{Monks and Nuns}

The central importance of the monasteries for the Syriac-Orthodox Church has long been recognized ${ }^{18}$. They hosted the patriarch, they gathered and guarded the libraries, and they entertained important schools. As recently pointed out, they also upheld important interregional relations and networks ${ }^{19}$. As fortified places they served as places of refuge $^{20}$. Suzan Ashbrook-Harvey and others have published important works on the female ascetic spirituality in Late Antiquity ${ }^{21}$, but for the $\mathrm{XI}^{\text {th }}$ to XIII ${ }^{\text {th }}$ century this is still a desideratum. Kawerau's assertion "from the rare notices one may conclude a minor importance of the medieval nuns" 22 has never been questioned.

Today the nuns live in shadow. As convents have long ceased to exist for reasons of security, nuns live in the same locations as the monks. They work in the background as agricultural workers and cooks. They wash and clean, whereas the monks are the teachers and priests. While

d'Antioche (1166-1199), I-IV, Paris, 1899-1924, reprint Brussels, 1963 (= MichaEL, Chronicle), IV, p. 602 (syr.) (III, p. 212 fr.); IV, p. 617 (III, p. 242), IV, p. 767-768 (III, p. 479-482); J.-B. Снавот (ed. and transl.), Anonymi Auctoris chronicon ad annum Christi 1234 pertinens (CSCO, 81; Script. Syr., 36 [syr.]; CSCO, 82; Script. Syr., 37 [syr.] CSCO, 109; Script. Syr., 56 [lat. v. of CSCO, 81]), Louvain, 1952-1953; A. AbouNA - J.-M. Fiey (transl. and comm.), Anonymi Auctoris chronicon ad a. C. 1234 pertinens 11 (CSCO, 354, Script. Syr., 154 [fr. v. of CSCO 82]), Louvain, 1974 (= ANONYMus AD A. 1234, Chronicon eccl./Chronicon prof. I-II), II, p. 331-333 (syr.) (II, p. 247-248 (fr.); and passim; KaWERAU, Die jakobitische Kirche, p. 17.

${ }_{18}$ Kawerau, Die jakobitische Kirche, p. 43-49.

19 F.e. K.C. INNEMÉE - L. VAN Rompay, La présence des Syriens dans le Wadi alNatrun (Égypte). À propos des découvertes récentes de peintures et de textes muraux dans l'Eglise de la Vierge du Couvent des Syriens, in Parole de l'Orient, 23 (1998), p. 167-202; L. VAN ROMPAY - A. SCHMIDT, Takritans in the Egyptian desert: The monastery of the Syrians in the ninth century, in Journal of the Canadian Society for Syriac Studies, 1 (2000), p. 41-59; K.C. INNEMÉE - L. VAN RoMPAY, Deir al-Surian (Egypt): New Discoveries of 2001-2002, in Hugoye, 5 (2002).

${ }^{20}$ Michael, Chronicle, IV, p. 647 (III, p. 290-291), and below, p. 332. 1998.

S. Ashbrook Harvey - S. Brock, Holy women of the Syrian Orient, Berkeley,

${ }^{22}$ Kawerau, Die jakobitische Kirche, p. 49. 
prelates and monks host the conferences, the nuns vanish with modest smiles after having served the meals. They attend service together and disappear again. Albeit their humble occupations, however, nuns in Mōr Gabriel as well as in Damascus count highly qualified professionals among them, for example psychologists, teachers and technical engineers. In Mōr Gabriel academics and non-academics alike do not only understand but also speak classical Syriac.

In Mōr Gabriel the nuns' presence is felt by the young seminarists, as they provide homemade food and give motherly affection. Their importance for female pilgrims, moreover, cannot be overestimated. Pilgrims flock from regions and cities in Turkey, Syria, Germany or Switzerland to Mōr Gabriel to pray mainly in cases of childlessness and for their handicapped or ill children. Affectionate attention from the nuns, collective preparation of the meals in the kitchen, eating, the washing up, tea, talk about legends about Saints and Martyrs, visits to the graves of the Saints led by the nuns, prayers with the nuns in the evenings on the rooftop of the monastery, interpretation of dreams, especially for those who spent the night on the floor in the church, conversations between nun and pilgrim about matters of marital relation are only the nuns' most obvious activities for the spiritual guidance of the women. The result is shown as an album full of thankful letters and photographs from all over the world, representing babies carrying the names Gabriel and Gabriela respectively. These are present observations, which bear no direct relevance for the historical study of the period under examination, but they open up a perspective for the very existence of a female culture closed to monks, scholars and husbands alike. Combined research efforts by anthropologists, archaeologists and historians could perhaps offer a glimpse also of the hidden life of medieval nuns.

\section{The communities}

Kawerau was very much interested in the co-operative aspects of the organisation of the Syriac-Orthodox Church ${ }^{23}$. The local community not only provided the financial means, asked the patriarch for certain prelates, or ousted others ${ }^{24}$. Together with the deacons, lay members of the community managed material aspects of the life of the church in various functions like treasure-keepers etc $^{25}$. It was not only a matter of ritual

${ }^{23}$ Kawerau, Die jakobitische Kirche, p. 49-54.

${ }^{24}$ Kawerau, Die jakobitische Kirche, p. 36, p. 52; Michael, Chronicle, IV, p. 613 (III, 232).

25 F. e. Anonymus ad A. 1234, Chronicon eccl., II, p. $92-93$ (II, p. 69-70). 
when the solemn acclamation by the community resounded after the election of a patriarch ${ }^{26}$. The hierarchy depended on its support. Therefore Kawerau outlined the structure of the social groups and position within the communities.

His observations can be taken a little further. For example the rich merchants, the scribes and the physicians most certainly supplied the local elite of the communities, the "notables" as Kawerau calls them. This elite, the lay myaqrē of a settlement, however, seems to consist of different groups and functions. While the rīšonn $\bar{e}^{-27}$ (presbyters) seem to form the ecclesiastical elite, the bnay-hir $\bar{e}$ (originally "free-born", „frank", "noble") are perhaps a high-ranking secular group, which however also was influential in ecclesiastical matters ${ }^{28}$. However, it has not been investigated by which qualification - vote or birth - members of the community became leaders, and how exclusive the various groups have been. The exact social meaning of the terms for the period is unclear.

It is equally difficult to evaluate the social status between the lay elite and the clerics. Of course the communities venerated their clerics. But for a young Syriac-Orthodox man with means and ambitions the church did not, in the same way, provide a road to erudition, power and wealth as did the Latin or the Greek Church. The church was present, in Baghdad and elsewhere, right at the centres of might and riches, but it formed no direct part of it. How were young priests recruited and for which reasons? Kawerau supposed the existence of priestly families ${ }^{29}$, a hypothesis which has not been examined on a systematic basis. One should also reconsider the relations between the priests and the deacons ${ }^{30}$. The deacons mastered a secular profession and practised it. Mentioned in the sources are physicians, philosophers, and astrologers ${ }^{31}$. Their low rank

${ }^{26}$ Kawerau, Die jakobitische Kirche, p. 17.

27 Kawerau, Die jakobitische Kirche, p. 51-52, see f.e. Bar 'EbrÖYÖ, Chronicon eccl. occ., p. 665 (p. 666-667)

28 ANONYmus AD A. 1234, Chronicon eccl., II, p. 297 (II, p. 222-223): "There was a monk from the Bnay-Ṣabūn̄i, called Raban Abu-Ḡâlib, the brother of Sa'îd, who had been metropolitan of Melitene... The men of Edessa were acquainted with him, especially those of the rǐšone of the city, who were originially from Melitene, and they liked him because of the kinship that had been between his fathers and them. And they wanted him to become the metropolitan of their city. And they instigated the rest of the rišsone and all the bnay-hisre to make them instigate the priests and the people to call him and to vote for him... And they chose men among the priests and the monks and the honourables (myaqrē) and send them to the patriarch."

29 KAWERAU, Die jakobitische Kirche, p. 71-73.

30 SELB, Orientalisches Kirchenrecht describes their liturgical functions, p. 242-244, p. 244-246 on the deaconesses, who are not mentioned in chronicles of the period under question.

31 Michael, Chronicle, IV, p. 622 (III, p. 264); P. Bedjan (ed.), Gregorii Barhebraei Chronicon Syriacum, Paris 1890; E.A.W. BUDGE (ed. and transl.), The Chronography of 
within the clergy is therefore not necessarily congruent with their position within the community or within the surrounding world ${ }^{32}$.

The structure of the community was also influenced by origin and family relations, defining certain groups and loyalties within a city. The Anonymous for example relates that in the middle of the XII ${ }^{\text {th }}$ century wealthy and influential Melitenians immigrated to Edessa. These immigrants gathered in the church Yōldat-Alōho in Edessa ${ }^{33}$. "In the other church Mōr Theodor, however, prayed workers, gardeners and people from the plain, who once had come from the plain of Edessa and settled in the city ${ }^{34}$." The rich and influential immigrants in one, the local working people in the other church - these kinds of differences shape interests, conflicts ${ }^{35}$ and the politics of the Syriac-Orthodox communities no less than the hierarchy of the church. In contexts like these we find hints of further social differentiation in the language of the chronicles, the 'ómüre (citizens) on the one hand, and the yōtbe (the settlers) on the other ${ }^{36}$. The Anonymous chronicler also mentions a couple of trades and occupations of citizens and by that gives an idea of the economic life of the Syriac-Orthodox and their social position.

Little is known about the life in rural areas. The lacks become apparent, as written sources are needed for the study of the historical context of churches in less prominent settlements in Syria, like Nabk or Qara ${ }^{37}$. Passages in the chronicles show, however, that Syriac-Orthodox Christians were not necessarily unimportant peasants in dependence of Muslim or Latin overlords. There clearly were Syriac-Orthodox landlords who owned estates. One example are the Bnay-Qry', who were "nōšin $y \bar{l} \underline{d} \bar{i}$ ' $\bar{e}$ " (notables, nobles) in the diocese of Amid. They lived in a qastrā

Gregory Abû'l Faraj, the son of Aaron, the hebrew physician commonly known as Bar Hebraeus being the first part of his political history of the world, I-II, Oxford - London, 1932, (= BAR 'EBRŌYō, Chronicon prof.) p. 203 (syr.) (p. 265 (engl.).

32 Compare Anonymus ad A. 1234, Chronicon eccl., II, p. 308 (II, p. 230).

33 Anonymus AD A. 1234, Chronicon eccl., II, p. 295 (II, p. 221).

34 Anonymus AD A. 1234, Chronicon eccl., II, p. 296 (II, p. 222), II, p. 308 (II, p. 231).

35 On conflicts between these two churches ANONYmus AD A. 1234, Chronicon eccl., II, p. 343 (II, p. 256).

36 ANONYMUS AD A. 1234, Chronicon prof., II, p. 58 (II, p. 42-43).

37 F.e. A.B. SChMidT - S. WestPhalen (ed.), Christliche Wandmalereien in Syrien. Qara und das Kloster Mar Yakub (Sprachen und Kulturen des Christlichen Orients, 14), Wiesbaden, 2005; E. CRUiKshank DodD, The Frescoes of MarMusa al-Habashi. A Study in Medieval Painting in Syria, (Studies and Texts, 139), Toronto, 2001 (= CRUIKSHANK DoDD, The Frescoes of Mar Musa); A.B. SCHMIDT, Zur kulturellen Identität der syrischen Christen im Qalamun. Das Kloster Jakobs des "Zerschnittenen" in Qara, in M. TAMCKE - A. Heinz (ed.), Die Suryoye und ihre Umwelt. 4. deutsches Syrologen-Symposium in Trier 2004. Festgabe Wolfgang Hage zum 70. Geburtstag (Studien zur Orientalischen Kirchengeschichte, 36), Münster - Hamburg - London, 2005, p. 171-183. 
called Qanqrat, where also an important monastery was situated. "And they of the Bnay-Qry' had farms and fields and they ruled this place ${ }^{38 "}$ reports the chronicle by patriarch Michael. At the same time the family was also influential in ecclesiastical matters, in Amid as well as in Edessa $^{39}$.

The word qastrā clearly has Latin origins, the relevance of which for the $\mathrm{XII}^{\text {th }}$ century however requires evaluation. The East Syrian dictionary of the $\mathrm{x}^{\text {th }}$ century by Bar Bahlul and his medieval additions in West and East Syriac, explains that qastrāa is synonym to Arabic hiṣn (castle) ${ }^{40}$. According to this dictionary the qastrā can also be understood as manz̧aratu hiṣn or madīnah hașinnah in Arabic and mdītō d-ḥesnō in Syriac, that is, a fortified city or town. Modem Syriac-Orthodox lexicographers still understand the term as "castle", "fortification"41, while qastra $\bar{a}$ in modem texts is also used to designate a town ${ }^{42}$. To conflate qastrā with qrītoo (village) clearly misrepresents its character ${ }^{43}$.

As there were Syriac-Orthodox, who šalițin waw, who ruled, there must have been subjects. At the time Kawerau did not investigate the bottom level of the communities, below the line of the free laymen. The Syriac-Orthodox population, however, also counted unfree people among them. The frequent wars in the regions filled the markets with slaves and prisoners of war. We know that Syriac-Orthodox were caught up in the wars and sold as slaves ${ }^{44}$. But laymen also possessed slaves themselves ${ }^{45}$.

As there are different terms for serfdom ('ab $\underline{d} \bar{o}, m \check{s} a$ ' $b \underline{d} \bar{o}$ ), there might have been different forms of bondage. We hear for example that monasteries owned $m s \breve{a} a b \bar{e}$. The influential translations of William Budge and Jean-Baptist Chabot use the term "subjects" or "serfs" respectively

38 MiChaEl, Chronicle, IV, p. 602 (III, p. 213).

39 Ibid.; MiChaEL, Chronicle, IV, p. 614 (III, p. 236); IV, p. 623 (III, p. 251).

40 R. PAyne SMITH, Thesaurus Syriacus, I-II, Oxford 1879-1901, reprint Hildesheim New York, 1981 (= PAYNE SMITH, Thesaurus), p. 3676 presents a quotation with qastrā awkit hesnō; R. Duval (ed.), Lexikon Syriacum auctore Hassano bar Bahlule, e pluribus codicibus edidit et notulis instruxit, Paris, 1901, p. 1815 (= BAR BAHLUL, Lexikon). On hisn see A.D.H. BIVAR, J.C. BotToms, art. Hịisn, in Encyclopedia of Islam (2 $\left.{ }^{\text {nd }}\right)$, III (1971), p. 498-503.

${ }^{41}$ S. HanNa - A. Bulut, Wörterbuch Deutsch-Aramäisch. Aramäisch-Deutsch, Heilbronn, 2000, p. 358: "Burg, Schloß, Fort, Festung".

${ }^{42}$ H. KaufHold, [Review of] M. TAMCKe (ed.), Syriaca: Zur Geschichte, Theologie, Liturgie und Gegenwartslage der syrischen Kirchen; 2. Deutsches Syrologen-Symposium (Juli 2000, Wittenberg), (Studien zur orientalischen Kirchengeschichte, 17), Miinster Hamburg - London, 2001, in Oriens Christianus, 87 (2003), p. 279-282, esp. p. 281-282.

${ }^{43}$ Michael, Chronicle, III, p. 213.

44 ANONYMUS AD A. 1234, Chronicon prof., II, p. 111 (II, p. 400).

45 BAR 'EBRŌYō, Chronicon prof., p. 280-81 (247-48). 
to represent this term ${ }^{46}$. Robert Payne-Smith suggested "mancipia monasterii" as a translation for $m s{ }^{\prime}{ }^{\prime} b \underline{d} \bar{e} d$ - "umró $\bar{o}^{47}$. It is highly unlikely that these $m \check{s} a^{\prime} b \underline{d} \bar{e}$ were slaves bought on markets, because $m \check{s} a$ ' $b \underline{d} \bar{e}$ of the monastery Mōr Barșawmō were Syriac-Orthodox Christians and fellow countrymen of some of the monks living there. Some of them were also armed ${ }^{48}$. Apparently the monastery had feudal rights in the region, and the $m \breve{s} a$ ' $b \underline{d} \bar{e}$ were subjects bound to the land or to the lordships respectively.

\section{The internal life of the Syriac-Orthodox church}

\section{Scientific studies}

Kawerau considered the general state of learning in this period to be dramatically low at that time. After intense philological research of the last 60 years the situation looks much better, while still little is known about the general state of education and the knowledge of Syriac in the communities. Socially the clerical scholars, the malponne, form a distinct group within the communities. They were secular clerics, prelates or monks versed in theology and philosophy as well as in important languages like Greek and Arabic. In the many inter-confessional encounters of the period they are seen defending their church and formulating its theological position. They were also the driving force in the reform movement of the period. At the same time they were also part of the centrifugal forces and sometimes seem rather unwilling to oblige less highly trained authorities ${ }^{49}$.

While Kawerau's focus has almost exclusively been on theologians it should be noted that there were also lay scholars and secular sciences. Little is known about them, for several reasons. The transmission of sources in the Syriac-Orthodox world is affected by persecution and destruction. These factors influenced the attitude to books and scholarship. Since it became necessary to plough back books in ecclesiastical buildings for reasons of safety, the books owned, written and used by secular scholars had little chance to survive in the long run. Secular libraries were also exposed to the interests of mighty and learned Muslim neigh-

46 BAR 'EBRōyō, Chronicon prof., p. 477 (408).

47 PAYNe SMITH, Thesaurus, p. 2771-2772.

48 MiChaEl, Chronicle, IV, p. 647 (III, p. 290-1).

49 Michael, Chronicle, IV, p. 609 (III, p. 226); IV, p. 625, (III, p. 252). A comparison to the Armenian vardapet presents itself, but has not as yet been undertaken, on the vardapets R. ThOmson, Vardapet in the Early Armenian Church, in Le Muséon, 75 (1962), p. 367-384. 
bours ${ }^{50}$. The poor remains therefore do not allow deducing the state of the secular sciences in the Syriac-Orthodox culture of that time.

One would wish for some more information on secular scholars and secular sciences in historical writing of the time. In the chronicle by Michael there are only some few remarks on secular sciences insofar as they were practiced by clergy. There are some more hints to the year 1234 in the Anonymous Chronicle, which generally allows for more insights into the daily life of the people. Bar 'Ebrōyo includes the most biographical notes on secular scholars in the Syriac World chronicle and even more in his Arabic chronicle. He followed Arabic-Muslim models, the tabaqāt, as Denise Aigle suggested ${ }^{51}$. Patriarch Barșawmō and Susanne Todt already had noticed that Bar 'Ebrōyō even quoted directly from the tabaqāt by Ibn Abi Ușaibi 'a and others ${ }^{52}$. But on the whole Bar 'Ebrōyō's remarks are isolated and cannot be corroborated by other sources. Not surprisingly Todt could identify only relatively few Arabic sources. As Muslim collections did not include all the Syriac or Christian writers important to the Syriac-Orthodox scholars, there must have been independent Syriac-Orthodox traditions ${ }^{53}$. Scarce as it might be, some prosopographic data extant in the chronicles, colophons and other sources were gathered by Patriarch Barșawmō in his monumental history of the Syriac literature ${ }^{54}$.

Additionally some more unspecific information might be of use, since for socio-historical research the names are not necessarily important. Manuscripts and their colophons also contain valuable socio-historical information about scholarly cultures. Helpful are studies on secular learning elsewhere in the region. One important example is Cécile Cabrol's study on the secretaries in the Abbasid administration ${ }^{55}$. While

50 Bar 'Ebrōyō, Chronicon eccl. or., p. 411 (p. 412); BaumSTARK, Geschichte der syrischen Literatur, p. 311.

51 D. AIGLE, Bar Hebraeus et son public à travers ses chroniques en syriaque et en arabe, in Le Muséon, 118 (2005), p. 3-31.

52 S. R. TODT, Die syrische und die arabische Weltgeschichte des Bar Hebraeus - ein Vergleich, in Der Islam, 65 (1988), p. 60-80; vgl. G.R. SMITH, art. Tabakät, in Encyclopedia of Islam (2 $\left.{ }^{\text {nd }}\right)$, X (2000), p. 7-10; I.A. BARȘAWM, Histoire des sciences et de la littérature syriaques [arab.], Glane, 1987; A. GORGIs - G. TORO (transl.), Geschichte der syrischen Wissenschaften und Literatur von Mor Ignatios Aphrem I. Barsaum Patriarch von Antiochien und des ganzen Ostens, Berlin, 2002, manuscript, p. 146-47 (= BARȘAWM, Geschichte der syrischen Wissenschaften).

53 See below, p. 326.

${ }^{54}$ BARȘAWM, Geschichte der syrischen Wissenschaften, p. 146-47.

55 C. CABROL, Les secrétaires nestoriens dans l'empire abbasside de 762 à 1258, in Parole de l'Orient, 25 (2000), p. 407-491 (= CABROL, Les secrétaires nestoriens); L. Cнеікно, Les vizirs et secrétaires arabes chrétiens en Islam 622-1517 (Patrimoine Arabe Chrétien, 11), Jounieh - Rom, 1987. 
the situation of the scholars of the Orthodox Church of the East differed in many respects, the study inspires questions on the West Syrian material. This is also true for studies on secular learning in the Latin world. Otto Gerhard Oexle ${ }^{56}$ for example distinguished "scholars" from "professionals". As alumni of the universities the latter earned a good living as powerful lawyers serving the kings or as city physicians. In the Syriac-Orthodox worlds there were young men, who used their training as capital to make a living. These professionals never intended to earn a place in the history of Syriac literature or theology, which is why they have been in the shade of theological and philological research, albeit their scientific knowledge.

Where would they have acquired their knowledge? Peter Kawerau and others, seem to know only churches and monasteries as centres of learning ${ }^{57}$. And it is true, during the $\mathrm{XII}^{\text {th }}$ century the cathedrals in Melitene and in Amid maintained schools. During the XIII ${ }^{\text {th }}$ century Patriarch Ignatius David sponsored ecclesiastical (yūlpōnēe 'idtōnōyē) and secular sciences (hekmat barōyē). „And everywhere he installed teachers and pupils at his own costs ${ }^{58}$ ". That is to say, he financed colleges, in which teachers and pupils were provided for. Probably the means were provided by endowments, as it was the case in the madrasas ${ }^{59}$ and the Latin colleges like the Sorbonne in Paris at that time.

But ecclesiastical schools and colleges can only have provided schooling for a part of the Syriac-Orthodox young men. The sources often do not mention a school but an individual teacher. These masters often were not Syriac-Orthodox scholars. Being close to them could have

56 O.G. OExLE, Alteuropäische Voraussetzungen des Bildungsbürgertums Universitäten, Gelehrte und Studierte, in W. CONZE - J. KocKA (ed.), Bildungsbürgertum im 19. Jahrhundert, Stuttgart, 1985, p. 29-78. For current methods and categories see also W.J. Courtenay - J. MiethKe (ed.), Universities and Schooling in Medieval Society, with the assistance of David B. Priest (Education and Society in the Middle Ages and Renaissance, 10), Leiden - Boston - Köln, 2000. On methods for the study of habitus and scholarly culture see the works by Gadi Algazi, for example G. ALGAZI, Scholars in Households: Refiguring the Learned Habitus, 1480-1550, in Science in Context, 16, 1-2 (2003), p. 9-42. Especially the forthcoming comparative study on Muslim, Christian and Jewish scholars is useful for an approach to Oriental Christian scholars: G. AlgAZI, Habitus, familia und forma vitae: Die Lebensweisen mittelalterlicher Gelehrten in muslimischen, jüdischen und christlichen Gemeinden - vergleichend betrachtet, in F. REXROTH (ed.), Zur Kulturgeschichte der Gelehrten im späten Mittelalter (in print).

57 KaWERAU, Die jakobitische Kirche, p. 56-59.

58 BAR 'EBRŌYŌ, Chronicon eccl. occ., p. 671 (p. 672).

59 R. HillenBRAND, art. Madrasa, in Encyclopedia of Islam (2nd), V (1986), p. 11231154. On the social history of schooling in Islam see also M. CHAMBERLAIN, Knowledge and social practise in medieval Damascus, 1190-1350 (Cambridge studies in Islamic civilization), Cambridge, 1995; J.E. LowRy (ed.), Law and Education in Medieval Islam. Studies in the Memory of George Makdisi, Warminster, 2004. 
its spiritual side-effects. Bar 'Ebrōyō assumed that the fact of studying with the Muslim Abū 'Ali Ibn-Walid led to the physician Yahya's (d. 1099) ${ }^{60}$ apostasy.

Bar 'Ebrōyō himself together with a friend studied in Tripoli with a teacher who was member of the Church of the East. Of course this is well known, but how exactly should this scene be put into perspective? How did this teacher, named Ya qūb, finance his work? Did he maintain a school in Crusader Tripoli? Or did he have only a couple of apprentices like a physician or a merchant? The renowned philosopher Kamal ad-Dīn Mūsā Ibn Yūnus in Mossul had several Syriac-Orthodox students who became well known scholars themselves ${ }^{61}$. It is not known in which fashion exactly these Christians were taught by him.

In pursuing their fortune, Syriac-Orthodox professionals seem to have been very mobile. Mention shall be made here of the Syriac-Orthodox physician, philosopher and astrologer Theodor of Antioch, who was one of the Christian students of Kamal ad-Dīn Mūsā Ibn Yūnus and later served at the court of Emperor Frederick II in Sicily ${ }^{62}$. Another example is the physician Hasnūn from Edessa. It seems that Syriac-Orthodox share the mobility with other Christian and Muslim professionals in the same period ${ }^{63}$.

To study also includes working with books. Syriac-Orthodox scholars and professionals were open to books by East Syrians and Muslims ${ }^{64}$. That is to say, they were part of the trans-cultural scientific world of the High Middle Ages, where scientific exchange between languages, religions or confessions was widespread. The chronicles suggest that language training, manuals, and often even the names of secular Syriac-Or-

${ }^{60}$ BAR 'EBRōyō, Chronicon prof', p. 266 (p. 236).

${ }^{61}$ Besides Theodor of Antioch for example the renowned scholar Ya'qūb bar Šakkō, s. BAUMSTARK, Geschichte der syrischen Literatur, p. 311.

${ }^{62}$ E. PoCOCKE (ed. and transl.), Historia Orientalis. Authore Gregorio Abul-Pharajio, Malatiensi medico: Historiam complectens universalem... Arabice edita, et Latine versa, Oxford, 1662, p. 521-2 (p. 341), for commentaries see B.Z. KEDAR - E. KOHLBERG, The Intercultural Career of Theodore of Antioch, in The Mediterranean Historical Review, 10 (1995), p. 164-176 and C.S.F. BURNETT, Magister Theodore, Frederick II's Philosopher, in Centro italiano di studi sull'alto medioevo Spoleto (ed.), Federico II e le nuove culture: Atti del XXXI Convegno storico internazionale, Todi, 9-12 ottobre 1994, Spoleto, 1995 , p. 225-285, who additionally gathered and translated all the Arabic and Western sources concerning Theodore, p. 255-85.

${ }^{63}$ See f. e. R. IRvin, Usama ibn Munqidh: An Arab-Syrian Gentleman at the Time of the Crusades reconsidered, in J. FRANCE - W. ZAJAC (ed.), The Crusades and Their Sources: Essays presented to Bernard Hamilton, Aldershot, 1998, p. 71-87; L. ConRAD, Ibn Butlān in Bilād al-Shäm: The Career of a Travelling Christian Physician, in D. Thomas (ed.), Syrian Christians under Islam: The First Thousand Years, Leiden Boston - Köln, 2001, p. 131-157.

${ }^{64}$ BAR 'EBRōyō, Chronicon eccl. ori., p. 409-413 (p. 410-414). 
thodox scholars and professionals were Arabic, not Syriac. As is well known, Bar 'Ebrōyō wanted to support Syriac as an up-to-date scientific language by providing encyclopaedias and collections in Syriac. While the Syriac-Orthodox scientific community had been familiar with the latest developments in the scientific world, they perhaps had not been very interested nor proficient in a Syriac apt for scientific use.

While the occupations of physicians, astrologers, philosophers or geometricians are known in principle, there are some Syriac terms for secular occupations which are unclear. They shall be discussed here briefly to open up the discussion. One of these terms is mlilo, rhetor. One of the renowned mlīle of the Syriac-Orthodox Church had been deacon and later bishop Dionysius bar Șalībī. The East Syrian teacher of Bar Ebrōyō also had been a mlīlō. But what exactly was the use of Syriac rhetoric from the $\mathrm{IX}^{\text {th }}$ to the $\mathrm{XIII}^{\text {th }}$ century and what did the mlile do for their living ${ }^{65}$ ?

Did they also teach the written language? To be versed in the written language was very useful to earn a living. Studying the written word according to Bar Ebrōyō included mlīlūt melțō d-egrōtōo, epistography. Still according to him, the Syriac-Orthodox students studied epistography with Arabic manuals. In Baghdad the Kitāb al-kuttāb by alBag̉dādī (written in about $868 \mathrm{CE}$ ) was used, among others ${ }^{66}$. Books like his must be what Bar Ebrōyō had in mind in this respect. They were written for the training of secretaries and notaries and taught different forms of official writing.

Quite regularly we come across nūmìqe in the chronicles by Bar Ebrōyō. They could be affluent enough to provide for a new church $^{67}$. Bar 'Ebrōyō's translators, Abbeloos and Lamy, suggest for this Greek loan word legisperiti or jurisperiti respectively, lawyers or advocates. However, they cannot have been like the Latin, Byzantine or Muslim

65 BAR BAHLUL, Lexikon, p. 1092-1093. On rhetoric in Syriac and its sources see the works by J. Watt, f.e. J.W. WATT, Antony of Tagrit on Rhetorical Figures, in H.J.W. DriJvers et al. (ed.), IV Symposium Syriacum 1984. Literary Genres in Syriac Literature (Orientalia Christiana Analecta, 229), Rom, 1987, p. 317-325, p. 325: „The study of rhetoric may therefore have had a long history in Syriac, possibly starting as early as the 5th century and extending... to at least the 13th (Barhebraeus), even although its sole literary monument is the Rhetoric of Antony of Tagrit." J.W. WATr (ed. and transl.), The fifth book of the rhetoric of Antony of Tagrit, I-II, (CSCO 480-481; Script. Syr., 203-204), Louvain, 1986; J.W. WATT, Aristotelian rhetoric in Syriac: Barhebraeus, Butyrum sapientiae, Book of rhetoric, with assistance of D. ISAAC, J. FAULTLESS and A. SHIHADEH (Aristoteles Semitico-Latinus, 18), Leiden, 2005.

${ }^{66}$ CABROL, Les secrétaires nestoriens.

67 BAR 'EBRōYō, Chronicon eccl. occ., p. 713 (p. 714); Chronicon eccl. ori., p. 445 (p. 446). 
lawyers. Bar Bahlul suggests two other terms as synonyms: nāwtārā and $k \bar{o} t u b l$ l-ešțärä. The term ešțärä being a certain form of contract in economical transactions ${ }^{68}$, the picture becomes somewhat clearer. SyriacOrthodox nümiqqe set up economical contracts and charters. The higher they moved up in the hierarchy of the elite the better their knowledge of civil law, style and calligraphy had to be.

As has been mentioned, their training and their occupation forced Syriac-Orthodox professionals and scholars out of the confines of their communities - socially, intellectually and even in matters of language and religion. This must have influenced their way of life as well as their cultural interests and tastes. The physician Hasnūn was one of them. He died in the year 1227 after having worked in many different cities and noble courts. Bar Ebrōyō relates of him: "He was an agreeable and corpulent old gentleman, he mastered the art of healing entirely and philosophy considerably... His acquaintance was very agreeable, and he remembered many tales about kings and scholars of the past as well as about those whom he saw in his own days ${ }^{69}$." Hasnūn's interest for tales about kings and scholars gives an all too rare glimpse of a secular and at the same time learned culture. He also is a missing link between the Muslim țabaqāt of scholars and the lost sources for Christian scholars mentioned above.

\section{Forms of spirituality - and secular life}

The short chapter on spiritual life of the communities in Kawerau's book deserves to be entirely rewritten. Too much was his outlook influenced by Orientalism and his low opinion of the state of learning in the communities. For a new approach the secular life of the communities should be included, which hitherto have been studied only very little. It is true, the secular culture of the lay communities vanished almost without leaving any traces. The media of this culture were of a more volatile kind, like songs, music, dances, jokes and stories ${ }^{70}$. In general one should avoid imagining the Syriac-Orthodox population of this period as austere and pietistic. Festivities of all kinds took place. Bar Ebrōyō had some advice about how to behave at grand banquets ${ }^{71}$ : One should not

${ }^{68}$ BAR Bahlul, Lexikon, p. 307, p. 1251, see also PAYNe Smith, Thesaurus, p. 2386.

69 BAR 'EBRŌYō, Chronicon prof., p. 457 (p. 392).

${ }^{70}$ See f.e. BAR 'EBRōyō, Chronicon prof., p. 457 (p. 392).

71 M. ABdallah, Culinary Issues in Bar Ebraya's Ethicon, in R. LAvENANT, S.J. (ed.), Symposium Syriacum VII. Uppsala University, Department of Asian and African Languages 11-14 August 1996 (Orientalia Christiana Analecta, 256), Rom, 1998, p. 735-745. 
blow on meals served too hot for immediate consumption, he says for example, but wait patiently until they were cooled down. When the banquets took place in the cities no doubt the affluent guests were dressed in the silk of the Syriac-Orthodox weavers and tailors mentioned in the sources $^{72}$. Their exquisite manners, their tastes and their fine cloths made at least the Suriani that is, the Arabic spoken Greek-orthodox Christians, look much too cultivated, even "effeminate" to the Latin chronicler William of Tyre, although he had grown up in the Near East $^{73}$.

The medieval houses of well-to-do Christian merchants in the cities or the powerful men of the large estates in the country were not described in the Syriac sources. But a Latin note about the coastal area draws the attention. The traveller Wilbrand of Oldenburg in the early $13^{\text {th }}$ century for example saw a room in the Crusader castle in Beirut decorated by local artists. He greatly admired the wall paintings in this room, "the ceiling of which is painted with such a suitable airy colour, that one can see here the clouds rush and there the West-wind blow and there the sun as it is dividing the year and the months, day and weeks and hours and the moments of its movement through the Zodiac. In all of these learned arts and beautiful works the Suriani, the Sarracens and the Greeks are very proud of themselves in the competition which is between them ${ }^{74}$." The Syriac-Orthodox most certainly took part in this competition ${ }^{75}$.

\footnotetext{
72 ANONYmUS AD A. 1234, Chronicon prof., II, p. 120 (II, p. 90); BAR 'EBRŌYō, Chronicon prof., p. 477-478 (p. 408-409).

73 R.B.C. HUYGENS (ed.), Willelmi Tyrensis archiepiscopi chronicon (Corpus Scriptorum Christianorum, Continuatio Mediaevalis, 63-63 A), Turnhout, 1986, XXII, 16 (15), p. 1029.

74 "Cuius testudo adeo proprie aërio colore depingitur, ut illic nubes discurrere, illic Zephyrus flare et illic sol annum et menses, dies et hebdomadas, horas et momenta suo motu in zodiaco videatur distinguere. In quibus omnibus Suriani, Sarraceni et Greci in magistralibus suis artibus quadam delectabili operis altercatione gloriantur." J.C.M. Laurent (ed.), Peregrinatores medii aevi quatuor. Burchardus de Monte Sion, Ricoldus de Monte Crucis, Odoricus de Foro Julii, Wilbrandus de Oldenborg, Leipzig 1864, p. 167; see also C. TEN HACKEN, The Description of Antioch in Abü al-Makärim's History of the Churches and Monasteries of Egypt and some Neighbouring Countries, in K. CiggaAR - M. MetCalf (ed.), East and West in the Medieval Eastern Mediterranean, I. Antioch from the Byzantine Reconquest until the end of the Crusader principality. Acta of the congress held at Hernen Castle in May 2003 (Orientalia Lovaniensia Analecta, 147), Leuven - Paris - Dudley/MA., 2006, p. 185-216, esp. p. 208.

75 H. TAKAHASHI, Aristotelian meteorology in Syriac: Barhebraeus, Butyrum sapientiae, books of mineralogy and meteorology (Aristoteles Semitico-latinus, 15), Leiden, 2004. On Astronomy in the XII ${ }^{\text {th }}$ and XIII ${ }^{\text {th }}$ century Syriac Orthodox society, see also D. WelteCKe, Die Konjunktion der Planeten im September 1186. Zum Ursprung einer globalen Katastrophenangst, in Saeculum, 54.2 (2003), p. 179-212.
} 


\section{Ecclesiastical building}

Kawerau observed a renewed effort in restoring and building new churches, albeit Muslim prohibitions. These activities are attested by the chronicles if not by archaeological remains. He also observed several assaults against Christian churches: Syriac-Orthodox were not only building new churches, they were also losing them at a rapid pace. Bar 'Ebrōyō's list of abandoned dioceses is an important witness to this development ${ }^{76}$. Archaeological studies indicate that in Syria and the Djazīra Syriac-Orthodox in some regions were leaving ancestral settlements ${ }^{77}$. Other places, however, like the Armenian Hromqla or Sis experienced increased activities ${ }^{78}$. The time of the $\mathrm{XII}^{\text {th }}$ and $\mathrm{XIII}^{\text {th }}$ century is seen as the period of the economical and political revival of the Muslim cities under the Seldjuks ${ }^{79}$. These changes must have had an effect, positive or negative, on the Syriac-Orthodox population.

\section{Internal decay}

The undercoat of Kawerau's tableau was his search for the relation between ideal and reality in the Syriac-Orthodox Church of the time, as indicated in the title of his work. To investigate this relation he compared normative sources and the evidence of the three great Syriac chronicles. Here, Kawerau's only but rather grave methodological mistake becomes apparent. Kawerau assumed that, as they were not flattering, the accounts in the chronicles represented reality ${ }^{80}$. Critical accounts, however, need just as careful source-critique as do words of praise. The countless moral invectives against clerics and lay-people are the bias of these works. The clericals who wrote them had reasons of their own to highlight the faults and the quarrels ${ }^{81}$. It is methodologically

76 BAR 'EBRŌYŌ, Chronicon eccl. ori., p. 459 (p. 460).

77 S. TALAY, Neue syrische Grabinschriften aus Qasrōk (Nordostsyrien) aus dem Jahre 327-330 H., in Oriens Christianus, 87 (2003), p. 80-99.

78 Bar 'EBrōyō, Chronicon eccl. occ., p. 665 (p. 666-667); A. SchmidT, Die zweifache armenische Rezension der syrischen Chronik Michaels des Großen, in Le Muséon, 109 (1996), p. 299-319.

79 S. Heidemann, Die Renaissance der Städte in Nordsyrien und Nordmesopotamien. Städtische Entwicklung und wirtschaftliche Bedingungen in ar-Raqqa und Harran von der Zeit der beduinischen Vorherrschaft bis zu den Seldschuken (Islamic History and Civilization. Studies and Texts, 40), Leiden, 2002.

${ }^{80}$ KAwERAU, Die jakobitische Kirche, p. 4: „Es bleiben also im wesentlichen nur die syrischen-jakobitischen Quellen selbst. Sie bieten genaue Schilderungen der eigenen kirchlichen Zustände: diese werden von ihnen so ungünstig dargestellt, dass ihre Angaben keine Bedenken erregen."

${ }_{81}$ On this bias of the chronicles D. WELTECKE, Überlegungen zu den Krisen der syrisch-orthodoxen Kirche im 12. Jahrhundert, in M. TAMCKE (ed.), Syriaca. Zur 
unsound simply to adopt their view. And there are also many elements of social and cultural life the chroniclers were not much interested in.

\section{The relations to other Christian churches and to secular powers}

As evidence for the Suriani has been used here twice to shed light on the history of the Syriac-Orthodox, this leads to the last two parts of Kawerau's book. Here, he discusses the relations between the SyriacOrthodox and other churches as well as other powers and religions. In general Kawerau came to the result that the miaphysitic sister-churches, the Armenians, the Copts and the Syriac-Orthodox Christians, managed to maintain relatively close cooperation during the stormy events of the period. Much has been said about the Syiac-Orthodox's hatred of the Greeks. A closer look into the sources reveals, however, that the seeming anti-Greek sentiment in reality was a sentiment against Greek-Orthodox Syrians, the afore mentioned Suriani ${ }^{82}$, with whom the Syriac-Orthodox population competed for resources as well as the Syriac identity.

Since Kawerau's days the ecumenical and polemical disputations between the denominations have often been the subject of detailed theological and church historical investigations. But for the relations on the local level the outcome of conferences between the high prelates or the disputations between the Mendicant missionaries and the patriarchs was only one factor.

Geschichte, Theologie, Liturgie und Gegewartslage der syrischen Kirchen, 2. Deutsches Syrologen-Symposium (Juli 2000, Wittenberg), (Studien zur Orientalischen Kirche, 17), Münster - Hamburg - London, 2002, p. 125-145.

82 J. Pahlitzsch, D. BARAZ, Christian Communities in the Latin Kingdom of Jerusalem (1099-1187 CE), in O. LIMOR - G.G. STROUMSA (ed.), Christians and Christianity in the Holy Land. From the Origins to the Latin Kingdoms (Cultural Encounters in Late Antiquity and the Middle Ages, 5), Turnhout 2006, p. 205-235; S. GRIFFITH, The Church of Jerusalem and the 'Melkites': The Making of and 'Arab Orthodox' Christian Identity in the World of Islam (750-1050 CE), in ibid., p. 175-204, p. 175-204; M. RuBIN, Arabization versus Islamization in the Palestinian Melkite Community during the Early Muslim Period, in A. Kofsky - G.G. STROUMSA (ed.), Sharing the Sacred. Religious Contacts and Conflicts in the Holy Land, First-Fifteenth Centuries CE, Jerusalem 1998, p. 149-162; M. RuBIN, The Language of Creation or the Primordial Language: A Case of Cultural Polemics in Antiquity, in Journal of Jewish Studies, 49 (1998), p. 308-333; J. Pahlitzsch, Graeci und Suriani im Palästina der Kreuzfahrerzeit (Berliner Historische Studien, 33), Berlin 2001. On Syriac-Orthodox polemic against the "Greeks" A. Mingana (ed. and transl.), Barșalibi's Treatise against the Melchites, Text and Translation, tr. p. 46, in Woodbrooke Studies. Christian Documents in Syriac, Arabic, and Garshüni I, Cambridge, 1927, p. 2-96 (= DionysuS bar ȘALīBī, Against the Melchite); J. Pahlitzsch, D. Weltecke, Konflikte zwischen den nicht-lateinischen Kirchen im Königreich Jerusalem, in D. BAUER, K. HERBERS, N. JASPERT (ed.), Jerusalem im Hochund Spätmittelalter. Konflikte und Konfliktbewältigung - Vorstellungen und Vergegenwärtigungen, Frankfurt - New York, 2001, p. 119-145. 
The denominations were no exclusive groups; they had a centre and a fringe, and there was considerable movement between them. Disappointed or ousted members of the different churches might wander from one denomination to another. All the while members of every status and age had to be taught the dogmatic tables up to ten and had to be remembered of them, to prevent too close contacts. Profuse heresiological writing $^{83}$ and certainly also preaching affirmed the differences between the groups and confirmed their identity ${ }^{84}$.

Different social groups defined by origin, family, social status and property within the confession have been mentioned. At the same time many cross-confessional and cross-religious relations existed, occasional violent outbursts notwithstanding. These could be personal relations like the friendship between a Suryōyō prelate, patriarch Athanasius, and a Surianus philosopher, 'Abdu 'l-Masị in the first half of the XII ${ }^{\text {th85 }}$. Especially new art historical findings furthermore suggest social relations. There are clearly aesthetic local traditions shared by all the confessions and religions living in the same area. There is a distinct "Syrian" or a "Takritan" style, shared by members of the different denominations, but not a "Syriac-Orthodox" style ${ }^{86}$. Commonly shared tastes of dress, jewellery and decoration become apparent, to which the remaining artefacts bear witness.

This leads to the hypothesis that Syriac-Orthodox were part of distinct cultural areas, depending on where in the Middle East they were living, the Levant, the Tūr 'Abdīn or the cities of Mesopotamia for example ${ }^{87}$. These cultural areas could have been another factor contributing to the

${ }^{83}$ F.e. Dionysus bar ȘALīBī, Against the Melchites. The addressee of this treatise is not a Greek adversary but a Syriac Orthodox monk who, to Dionysius' taste, was far too tolerant with other confessions.

${ }^{84}$ A pioneer project under the auspices of Robert B. Ter Haar Romeny on SyriacOrthodox in Leiden has recently come to a first conclusion. The publications by this group are central for the study of the social and cultural history of the Syriac-Orthodox Christians.

${ }^{85}$ Michael, Chronicle, IV, p. 599 (III, p. 209).

${ }^{86}$ To mention some important recent publications: M. IMMERZEEL, Holy Horsemen and Crusader Banners. Equestrian Saints in Wall Paintings in Lebanon and Syria, in Eastern Christian, Art 1 (2004), p. 29-60; B. SNELDERS - M. IMMERZEEL, The ThirteenthCentury Flabellum from Deir al-Surian in the Musée Royal de Mariemont (Morlanwelz, Belgium), in Eastern Christian Art, 1 (2004), p. 113-139; L.A. HunT, Byzantium, Eastern Christendom and Islam. Art, at the Crossroads of the Medieval Mediterranean, I-II, London, 1998; Cruikshank Dodd, The Frescoes of Mar Musa.

87 For this approach see f.e. R. BENEDICT, Patterns of Culture, New York, 1949. Cultural areas themselves are no monolithic entities, see also U. GOTTER, "Akkulturation" als Methodenproblem der historischen Wissenschaften, in W. EssBaCH, (ed.), Wir - ihr sie. Identität und Alterität in Theorie und Methode (Identitäten und Alteritäten, 2), Würzburg, 2000, p. 373-406. 
gradual drifting apart of the regions and to the schisms of the coming centuries. Similar differences within the Armenian community were described by Nerses of Lampron in the late II $^{\text {th }}$ century. He observed not only a Persian way to dress versus the Cilician-Latin style as distinguishing the Armenian elites in Ani from those in Cilicia. Nerses saw different mentalities and customs. He interpreted them as one of the reasons for internal spiritual conflicts within the Armenian Church ${ }^{88}$. And the church indeed split along the lines of these borders soon afterwards. Kawerau's approach to these macro-social factors seems outdated now as was the case with his interpretations of internal conflicts.

New observations present themselves concerning the relations between Syriac-Orthodox and their rulers of different religion or denomination. Kawerau had made it very clear that the representatives of the church depended on the good will of the secular forces and of their official recognition. The diploma were usually issued as a matter of course, but this was still an element of control over the Syriac-Orthodox Church, which Jocelyn II of Courtenay for one was using actively. The metropolitan Basil bar Šumnē by name, was accused of having taken the See of Edessa by the order of the count. Basil tried to clear his name by writing a pamphlet against this accusation ${ }^{89}$. The case of Bishop Basil, however, betrays some means of subaltern agency of Syriac-Orthodox elites. For at the same time members of the family of the Šmne were also involved in the Latin administration. They were part of the elite of SyriacOrthodox Edessenians securing their influence through cooperation with the rulers.

And so they did after the fall of Edessa in the year $1144^{90}$. Basil for one immediately promised loyalty to the conqueror, the mighty Atabeg Zengi. Alternating relations and coalitions like these have often been

88 Nerses von LAmpron, Lettre adressée au roi Léon $1 l$, in E. DULAURIER (ed.), RHC Documents arméniens I, 1869, p. 579-603, esp. 596-599. See also K. PINGGÉRA, Nerses von Lambron und die armenische Kirche des 12. Jahrhunderts. Erneuerung und Identität in Konflikt, in M. TAMCKE (ed.), „Dich, Ararat, vergesse ich nie! “ Neue Beiträge zum Schicksal Armeniens und der Armenier (Studien zur Orientalischen Kirchengeschichte, 40), Münster, 2006, p. 25-46. On the cultural differences between Cilicia and Great Armenia and their different perspective on the Crusades see J.J. WeitenBerg, Literary Contacts in Cilician Armenia, in K. CiggaAR - A. Davids - H. Teule (ed.), East and West in the Crusader States. Context - Contacts - Confrontation, Leuven, 1996, p. 63-72; R.W. Thomson, The Crusaders through Armenian Eyes, in E.A. LAIOU R.P. MOTrAHEDEH (ed.), The Crusades from the Perspective of Byzantium and the Muslim World, Dumbarton Oaks, 2001, p. 71-82.

89 MiChael, Chronicle, IV, p. 628 (III, p. 259).

90 Anonymus AD A. 1234, Chronicon prof., II, p. 132-6 (II, p. 99-102). A Sōhdō bar Sumne was one of the candidates for the succession of Basil in 1169. ANONYMUS AD A. 1234, Chronicon eccl., II, p. 308-309 (II, p. 321). 
moralized in the scholarly literature of the last hundred years. Ethical terms like "friendship", "cordiality" versus "disloyalty" or "traitors" have been used. Cooperation however does neither make traitors, nor is it necessarily a sign of tolerance or friendship. It simply was inevitable, for both sides. And it should be neutrally interpreted as a means of subalterm agency of the Syriac Orthodox subjects ${ }^{91}$. Their special secular occupations also functioned as a means of agency. A notary or a physician at the courts meant having an ear at the heart of power to know timely about political and military changes. It also provided advocates of the communities beside the representatives of the $\operatorname{church}^{92}$. These were no life insurance, but they were a medium of control the Syriac-Orthodox could use.

Means of agency can even be seen in peace and war, a hitherto neglected subject of research. The presence of the Latins all in all destabilized the situation of the Easterm Christians in the Middle East. All the Eastem Christian denominations in Melitene or in Aleppo for example were held responsible for the deeds of the Latin count Jocelyn II Courtenay. His actions against mosques were prompted in Aleppo by prohibitions of worship, by the collection of special taxes to pay for the damage, by the plundering and the loss of churches and monasteries ${ }^{93}$. At the same time, Christians were legally excluded from military services $^{94}$. Occasionally, however, Syriac-Orthodox were actively involved in military action on the side of the Latins or certain Muslim rulers. In cases of emergency, bishops were in charge of the command ${ }^{95}$. A maphrian even is reported to have heroically defended the Syriac-Orthodox of Amid with his own hands ${ }^{96}$. The monasteries served as castles, and in times of assault they were apparently defended not only by Syriac-Orthodox nōtūrē, armed watchmen, but also by the monks themselves ${ }^{97}$. The Syriac-Orthodox counted archers among them, who were also used in Muslim contingencies ${ }^{98}$. It seems that neither of the secular powers of the regions provided for efficient protection of the Syriac-

91 On agency of subaltern groups see J.C. ScoTt, Domination and the Arts of Resistance: Hidden Transcripts, New Haven - London, 1990.

${ }_{92}$ Michael, Chronicle, IV, p. 386 (III, p. 723).

93 ANONYMUS AD A. 1234, Chronicon prof., II, p. 92 (II, p.69).

94 A. FATTAL, Le statut légal des non-musulmans en pays d'Islam (Recherches publiées sous la direction de l'Institut de lettres orientales de Beyrouth, 10), Beyrouth, 1958 , p. 232-233, p. 233-236 on exceptions from the rule.

95 BAR 'EBRōyō, Chronicon prof., p. 477-478 (p. 408-409).

96 BAR 'EBRōyō, Chronicon eccl. ori., p. 405 (p. 406).

97 Michael, Chronicle, IV, p. 696-698 (III, p. 340-342); BAR 'EBRōyō, Chronicon prof., p. 516-517 (p. 440-441).

98 BAR 'EBRŌYō, Chronicon eccl. occ., p. 474 (p. 405). 
Orthodox, which made a certain expertise in self-defence inevitable, but also possible. Secular powers also levied auxiliary troops by force, clerics and monks included ${ }^{99}$.

\section{Conclusion}

The aim of this contribution was to reread the path breaking study by Peter Kawerau in order to systematise some findings and to reflect on the present state of research. Gaps in Kawerau's tableau of the social structure of the Syriac-Orthodox Church as well as desiderata of research in general became thus apparent. Kawerau's tableau, however, is obviously flexible enough to provide the frame into which new systematic elements can be added. It therefore still seems an excellent starting point for research in the social and cultural history.

New research questions arose mainly in the fields of female religiosity versus male religiosity and church hierarchy, secular professionals and secular scholars versus ecclesiastical scholars, social structures of lay groups, either in the city or in rural areas, elite and underprivileged. In studying these elements of social history the meaning of several terms for forms of settlement, social positions or occupations proved to be unclear, let alone the social structures designated by them.

The fact that the Syriac-Orthodox Church had a secular side and its members shared secular forms of cultural life so far drew little attention. But the division between church and world or religious and secular life clearly was a reality experienced by Syriac-Orthodox Christians in a Muslim, Mongol, Byzantine or Latin environment. Only parts of the members of the church were constantly involved with ecclesiastical matters, built their careers on the church or formed their habitus through it. Others, like professionals and merchants, had to constantly interact with members of different religions and cultures. By their training, their occupations and their environment the secular scholars and professionals developed different cultural interests and forms than those known from the clerical sources written in Syriac.

99 J.J.S. Weitenberg, The Armenian Monasteries in the Black Mountain, in K. CiggaAR - M. MetCalf (ed.), East and West in the medieval Eastern Mediterranean, $I$. Antioch from the Byzantine Reconquest until the end of the Crusader principality. Acta of the congress held at Hernen Castle in May 2003 (Orientalia Lovaniensia Analecta, 147), Leuven - Paris - Dudley/MA, 2006, p. 79-93, esp. p. 80: Emperor Romanos III ordered ,heretical' monks on the Black Mountain to be incorporated in his army. These monks probably were Syriac-Orthodox and Armenian monks. On Christians in auxiliary troops see also J. RICHARD, Les Turcopoles au service des royaumes de Jérusalem et de Chypre: Musulmans convertis ou chrétiens orientaux, in Revue des études islamiques, 54 (1986), p. 259-270. 
The critical technique Kawerau used to evaluate the data provided by these sources seems to be the more questionable element of his work, especially as it caused some untimely judgements. To take the negative perspective of the chronicles as the reality versus the ideal prescribed in the normative sources cannot be considered a convincing method nowadays. The same is true of the sometimes moral judgements of the complicated and conflict-ridden history of the Church. Here, new sociological approaches to analyse conflict, dysfunction and failure within the wider context of the Muslim and Latin societies should be tried. Questions of group identity, of the boundaries of cultural areas and of crossreligious relations present themselves. Here, too, theoretical and empirical methods to describe subaltern groups and religiously mixed cultures have been established during the last decades, which were not available at Kawerau's times and which could now show the struggle of the Syriac-Orthodox societies in a different light.

Compared to the state of the arts in the study of the Latin Middle Ages or of Muslim societies the social and cultural history of the SyriacOrthodox Church is still at its beginning. Through Spuler's initiative, however, Kawerau and other scholars started to analyse the history of the Syriac-Orthodox Church not only as the history of a religious institution, but as the history of social groups within the Near Eastern societies. This achievement remains a landmark and a challenge to present day research.

\author{
Universität Konstanz \\ Fachbereich Geschichte und Soziologie \\ 78457 Konstanz, Deutschland \\ dorothea.weltecke@uni-konstanz.de
}

\title{
Dorothea WeLTECKE
}

Abstract - The paper takes the opportunity of the 60th anniversary of the completion of Peter Kawerau's doctoral dissertation „Die jakobitische Kirche im Zeitalter der syrischen Renaissance: Idee und Wirklichkeit" to discuss its merits and disadvantages as well as the present state of social historical research. Thanks to its systematic approach, Kawerau's work proves an excellent starting point for research in social and cultural history even today. New research questions arose mainly in the fields of female religiosity versus male religiosity and church hierarchy, secular professionals and secular scholars versus ecclesiastical scholars, social structures of lay groups, either in the city or in rural areas, elite and underpriviledged. At the same time theoretical and empirical methods have been established during the last decades, which were not available at Kawerau's times. Compared to the state of the arts in the study of the Latin Middle Ages or of Muslim societies the social and cultural history of the Syriac-Orthodox Church is still at its beginning. Through Bertold Spuler's 
initiative, however, Peter Kawerau developed a systematic approach for the analysis of the history of the Syriac-Orthodox Church not only as the history of a religious institution, but as the history of a social group within the Near Eastern worlds. This achievement remains a landmark and a challenge to present day research.

\section{APPENDIX}

Peter KaWerau, Die jakobitische Kirche im Zeitalter der syrischen Renaissance. Idee und Wirklichkeit, Berlin 1960:

\section{Translation of the table of contents}

THE ORGANISATION OF THE JACOBITE CHURCH

Patriarch

Maphrian

Metropolitans and bishops

Abbots

Monasteries

Monks and nuns

Communities

THE INTERNAL LIFE OF THE JACOBITE CHURCH

Scientific studies

Forms of spirituality

Ecclesiastical building

Internal decay

Striving for reform

THE RELATIONS OF THE JACOBITE CHURCH TO THE OTHER ChRISTIAN CHURCHES

Copts

Armenians

Nestorians

Greeks

Occidental Christianity (Crusaders)

THE RELATIONS TO THE NON-CHRISTIAN ENVIRONMENT

The official diploma for the prelates

THE RELATIONS TO THE MUSLIM GOVERNMENT

The relations to the Mongol government

The cohabitation of Christians with Muslims and Jews 